\title{
Growth Inhibitory Effect of 2-Nitropropanol on Foodborne Bacteria of Public Health Importance
}

\author{
Suresh Chandra Das*, Pramod Kumar Nanda and Uttam Kumar Bandyopadhyay
}

Eastern Regional Station, ICAR-Indian Veterinary Research Institute, 37, Belgachia Road, Kolkata-700 037, West Bengal, India

*Corresponding author

\section{Keywords}

2-nitropropanol, Chick, Minimum inhibitory concentration, Salmonella typhimurium, Salmonella gallinarum, Shigatoxic E. coli

Article Info

Accepted:

17 November 2018

Available Online:

10 December 2018

\section{A B S T R A C T}

The investigation was aimed at to proximate the minimum inhibitory concentration (MIC) of 2-nitropropanol (2-NPOH) for growth inhibition (in-vitro) of Salmonella typhimurium, Shigatoxic Escherichia coli (STEC) and Salmonella gallinarum vis a vis effect of $\mathrm{pH}$ of culture medium on function of 2-NPOH and its in-vivo effect on these bacteria in chick model. In in-vitro testing, MIC of 2-NPOH for Salmonella typhimurium was recorded to be $3.5 \mathrm{mM}$ whereas it was $1.5 \mathrm{mM}$ for STEC and Salmonella gallinarum. These organisms were sensitive to acidic $\mathrm{pH}$ of the growth medium. Increasing $\mathrm{pH}$ of the medium viz. 7.3, 8.0, 8.5, 9.0 and 9.5 (without adding 2-NPOH) revealed that higher alkalinity did not affect growth status of these organisms. On the analogy, growth medium supplemented with subMIC dosage of 2-NPOH in different alkaline $\mathrm{pH}(8.0,8.5,9.0$ and 9.5) although exerted its bacteriostatic effect; but had no significant variation on growth at different $\mathrm{pH}(>8.0)$. Invivo effect of 2-NPOH in chick model (4 days old) revealed that its MIC dosages may considerably reduce carriage of intestinal bacteria like Salmonella typhimurium $\left(26 \times 10^{7}\right.$ to $10.5 \times 10^{6} \mathrm{cfu} / \mathrm{gm}$ of faeces), STEC $\left(33 \times 10^{7}\right.$ to $11.2 \times 10^{6} \mathrm{cfu} / \mathrm{gm}$ faeces) and Salmonella gallinarum ( $29 \times 10^{7}$ to $9.4 \times 10^{6} \mathrm{cfu} / \mathrm{gm}$ of faeces). Above all, the findings suggested that 2 NPOH may be used as substitute of antibiotic to reduce the carriage of gut microbiota of public health importance in poultry.

\section{Introduction}

Despite of adopting recommended measures and intensive precautions for prevention of contamination in food processing, storage and supply; foodborne outbreaks in human continue to occur (Yang et al., 2017). CDC estimates that each year 48 million people get sick from a foodborne illness, 128,000 are hospitalized, and 3,000 die in the U.S. (CDC, 2018). Annual summary of CDC Report documented in 2016 reveals a total of 839 foodborne disease outbreaks, resulting in 14,259 illnesses, 875 hospitalizations, 17 deaths, and 18 food recalls wherein Salmonella, STEC, Clostridium perfringens and Norovirus were detected to be the leading pathogens. Further, in 2010 there was report of 600 million of foodborne illness globally and 4,20,000 deaths where the most frequent causes of foodborne illness were diarrhoeal disease agents, particularly Norovirus and 
Campylobacters followed by non-typhoidal Salmonella enterica, and also Salmonella typhi, Taenia solium, hepatitis A virus, and aflatoxin (WHO, 2015). An estimated annual 300,000 hospitalizations and 5000 deaths in the U.S. alone are related to food-borne illnesses; which reflects economic implications costing the US economy more than $\$ 15.6$ billion (USDA, 2014). The economic loss of food poisoning outbreaks in developing country like Indonesia in 2013 was approximately US\$ 78 million (Rahayu et al., 2016).

Efforts to reduce the carriage of the intestinal pathogens in food animals have been made in veterinary medicine by use of antibiotics; however, this induces the emergence of antibiotic resistant bacterial strains that pose a burgeoning burden in public health (Hao et $a l ., 2014)$. To avoid this, in recent past, the approach of using innovative strategies such as prebiotic, probiotic, immunomodulators, bacterial growth inhibition by various chemicals/ constituents, bacterial antagonism by saprophytes etc. have gained momentum as substitute to antibiotics (Strompfova and Laukova, 2007). The bacteriocin 'Enterocin AS-48' produced by Enterococcus is widely used in packed food industry as a natural food bio-preservative against a list of food borne and food spoilage pathogens (Grande Burgos et al., 2014; Ortega et al., 2018). Reduction of harmful aerobic intestinal bacteria (having the nitrate reductase enzyme) in food animals using the chlorate compound is also a promising approach (Anderson et al., 2005) where aerobic bacteria by virtue of their respiratory nitrate reductase enzyme can metabolize nitrate that in turn converts inorganic chlorate to cytotoxic chlorite. Interestingly, most of the beneficial anaerobic gut bacteria lack respiratory nitrate reductase activity and escape the experimental chlorate cytotoxic action. Thus chlorate may selectively target those gut bacteria possessing a respiratory nitrate reductase enzyme (mostly aerobes) but not the beneficial anaerobes lacking the enzyme; thereby, conserving the competitive exclusion potential of the host's normal flora (Anderson et al., 2000). Many efforts have been made for reduction and possible elimination of pathogens during all stages of production in order to prevent the foodborne problems (Jung et al., 2004; Anderson et al., 2005); however, none of the measures alone stands as absolutely effective.

Ability of potential probiotic strains to adhere to the intestinal mucosa and exclude \& displace pathogens is of utmost importance for therapeutic manipulation of the enteric microbiota (Cassir et al., 2016). Besides, literature review suggests that different group of researchers have studied with different chemicals like nitrate and chlorate (Jung et al., 2003; Anderson et al., 2005), 2-nitro-1propanol \& 3 nitro-1-propanol (Jung et al., 2004), 2-NPOH along with 2-nitroethanol (Adhikari et al., 2016; Adhikari et al., 2017) to explore their effects to reduce the carriage of intestinal pathogens as well as to evade the use of antibiotics and thereby, emergence of resistant strains. Although limited researches have been carried out in this line in abroad; however, no such synchronised study, so far, has been recorded in Indian context. Considering the back ground information, the present investigation was aimed at to evaluate the potentials of 2-NPOH as an alternative of antimicrobial supplement in food chain in order to minimize the foodborne problems with commonly occurred aerobic bacteria viz. Salmonella typhimurium and STEC.

\section{Materials and Methods}

\section{Reference culture}

Reference cultures of Salmonella typhimurium and STEC were obtained by kind courtesy of Department of Microbiology, National 
Institute of Cholera and Enteric Diseases (NICED), Kolkata, India. Considering the host animal's susceptibility and suitability, Salmonella gallinarum, included as reference culture to assess the in-vivo effect of 2-NPOH in chick, was obtained from ICAR-Indian Veterinary Research Institute, Izatnagar, Bareilly, U.P., India.

Determination of minimum inhibitory concentration (MIC) of 2-NPOH (in-vitro)

Molar solution of 2-NPOH was prepared in triple distilled water and made sterile by filtering through syringe filter (Milipore; 0.22 $\mu \mathrm{m})$ on the laminar flow. Calculated volume of such 2-NPOH solution was added to preautoclaved Tryptic Soy Broth (TSB) to make different molar final concentration $(1.0 ; 1.25$; $1.5 ; 2.0 ; 2.5 ; 3.0,3.25$ and $3.5 \mathrm{mM}$ ) of $2-$ $\mathrm{NPOH}$ in TSB and the prepared TSB were kept overnight at $37^{\circ} \mathrm{C}$ to check sterility. On the next day, the bottle of TSB (found no growth) was inoculated with the target bacterial culture and observed for growth (turbidity and test plate culture) at 6, 12, 24, 48, 96 and $120 \mathrm{hrs}$ of incubation. The TSB supplemented with 2-NPOH and exhibited no growth up to $120 \mathrm{hrs}$ was kept under observation up to two weeks to check growth, if any, of inoculated bacteria. MIC of 2-NPOH for in-vitro growth inhibition of Salmonella gallinarum was assessed in this study for evaluation of its in-vivo effect in chicks.

Isolates of STEC $(\mathrm{n}=12)$ and Salmonella gallinarum $(\mathrm{n}=5)$ obtained from field samples were assessed (in-vitro) for effect of 2-NPOH following the same method as mentioned above for reference culture.

Effect of 2-NPOH on growth logarithm of test cultures

To understand the effect of 2-NPOH on growth logarithm of the test bacteria, the cultures were grown in medium without 2$\mathrm{NPOH}$ and vis-à-vis with use of $2-\mathrm{NPOH}$ (sub- MIC dosages) and colony count was recorded in different span of incubation (6 hrs, $12 \mathrm{hrs}$ and $24 \mathrm{hrs}$ ).

\section{Effect of $\mathrm{pH}$ of culture medium on growth logarithm of test culture}

To know the effect of $\mathrm{pH}$ on growth of the test organisms, $\mathrm{pH}$ of the medium (TSB) without supplement of 2-NPOH was adjusted to 5.0, 6.0, 6.5, 7.3 (dehydrated medium $\mathrm{pH}$ ), 8.0, $8.5,9.0$ and 9.5 and were incubated on inoculation with the test organisms.

Findings for growth of the test culture in TSB (without 2-NPOH) indicate that none of the test culture grow in the medium having $\mathrm{pH}$ below 7.3. Therefore, TSB was prepared with $\mathrm{pH} 7.3,8.0,8.5,9.0$ and 9.5 to assess the effect of 2-NPOH in different alkaline $\mathrm{pH}$. Further, such growth medium was supplemented with sub-MIC doses of 2$\mathrm{NPOH}$ to evaluate the bacteriostatic effect of $2-\mathrm{NPOH}$ in variable $\mathrm{pH}$ of growth medium.

\section{In vivo effect of 2-NPOH in chick model}

In-vivo effect of 2-NPOH was studied using 4 days old chick in different groups [control (1) and study groups (4)]. Each group consisted of 6 birds. At the beginning, total bacterial count (TBC) per gram of faecal content was assessed in the birds of control as well as first study group (where no 2-NPOH was used) by serial dilution of faeces in peptone water followed by spread plating onto the Mueller Hinton agar (MHA) (average of count was considered as value). Likewise, 2-NPOH (MIC dose) was fed in the first study group and TBC per gram of faeces was assessed (average of count was considered as value) after 24 hrs. Intestinal bacterial load was counted in the second study group and thereafter, fed with young culture of STEC 
grown overnight in TSB $\left(\sim 10^{6} \mathrm{cfu}\right)$, and TBC per gram of faeces was recorded after $24 \mathrm{hrs}$. Then, 2-NPOH (MIC dose) was given orally to this study group and TBC per gram of faeces was noted after $24 \mathrm{hrs}$.

Similar to the second study group, chicks in the third study group were fed with $\sim 10^{6} \mathrm{cfu}$ of novobiocin $(25 \mu \mathrm{g})$ and nalidixic acid $(20 \mu \mathrm{g})$ resistant Salmonella typhimurium culture grown overnight in TSB and TBC per gram of faeces was recorded after $24 \mathrm{hrs}$. Thereafter, 2-NPOH (MIC dose) was given orally to this study group and TBC per gram of faeces was noted after $24 \mathrm{hrs}$ by diluting the collected faeces from such birds in peptone water and thereafter, spreading onto the Brilliant Green Agar (BGA) supplemented with novobiocin $(25 \mu \mathrm{g} / \mathrm{ml})$ and nalidixic acid $(20 \mu \mathrm{g} / \mathrm{ml})$ to enumerate Salmonella typhimurium. Similarly, such assessment of 2-NPOH was also done for Salmonella gallinarum in fourth study group.

\section{Results and Discussion}

On in-vitro assay for determination of MIC of $2-\mathrm{NPOH}$, it was observed that $3.5 \mathrm{mM}$ of 2$\mathrm{NPOH}$ was the MIC for Salmonella typhimurium and $1.5 \mathrm{mM}$ for STEC and Salmonella gallinarum (Table 1).

In the growth medium free from $2-\mathrm{NPOH}$, Salmonella typhimurium exhibited $7 \times 10^{6} \mathrm{cfu} /$ $\mathrm{ml}, 20 \times 10^{6} \mathrm{cfu} / \mathrm{ml}$ and $41 \times 10^{6} \mathrm{cfu} / \mathrm{ml}$ in $6 \mathrm{hrs}$, $12 \mathrm{hrs}$ and $24 \mathrm{hrs}$ of incubation, respectively (Table 2). Likewise, for STEC, $20 \times 10^{6} \mathrm{cfu} / \mathrm{ml}$, $65 \times 10^{6} \mathrm{cfu} / \mathrm{ml}$ and $170 \times 10^{6} \mathrm{cfu} / \mathrm{ml}$ was recorded in $6 \mathrm{hrs}, 12 \mathrm{hrs}$ and $24 \mathrm{hrs}$ of incubation. Similarly, for Salmonella gallinarum, it was $11 \times 10^{6} \mathrm{cfu} / \mathrm{ml}, 35 \times 10^{6}$ $\mathrm{cfu} / \mathrm{ml}$ and $150 \times 10^{6} \mathrm{cfu} / \mathrm{ml}$, respectively in 6 hrs, $12 \mathrm{hrs}$ and $24 \mathrm{hrs}$ of incubation (Table 2).

When Salmonella typhimurium was allowed to grow in the medium supplemented with immediate sub MIC $(3.0 \mathrm{mM})$ of $2-\mathrm{NPOH}$
(MIC is $3.5 \mathrm{mM}$ ), it revealed $70 \times 10^{3} \mathrm{cfu} / \mathrm{ml}$, $1.7 \times 10^{6} \mathrm{cfu} / \mathrm{ml}$ and $2.5 \times 10^{6} \mathrm{cfu} / \mathrm{ml}$, respectively in $6 \mathrm{hrs}, 12 \mathrm{hrs}$ and $24 \mathrm{hrs}$ of incubation (Table 2). Similarly, the STEC in its immediate sub-MIC (1.0 MM) of 2-NPOH revealed $1.4 \times 10^{6} \mathrm{cfu} / \mathrm{ml}, 2.4 \times 10^{6} \mathrm{cfu} / \mathrm{ml}$ and $3.5 \times 10^{6} \mathrm{cfu} / \mathrm{ml}$ in $6 \mathrm{hrs}, 12 \mathrm{hrs}$ and $24 \mathrm{hrs}$ of incubation (Table 2). Likewise, for Salmonella gallinarum, it was $75 \times 10^{3} \mathrm{cfu} / \mathrm{ml}, 1.5 \times 10^{6}$ $\mathrm{cfu} / \mathrm{ml}$ and $2.7 \times 10^{6} \mathrm{cfu} / \mathrm{ml}$, respectively in 6 hrs, $12 \mathrm{hrs}$ and $24 \mathrm{hrs}$ of incubation (Table 2). The observation focused that the growth rate of the above three bacterial species was significantly reduced with the use of $2-\mathrm{NPOH}$ in its sub-MIC. It appears that even in subMIC doses, 2-NPOH facilitates its bacteriostatic property on the tested foodborne bacterial pathogens.

The present findings support the observations of earlier study by Jung et al., (2004). Since, few published works are available on this aspect, the present findings could not be thoroughly discussed with comparison. The study observation is in accord to the trend of result in the experiment by Jung et al., (2004) and Adhikari et al., (2016) where they have recorded considerable growth inhibition effect at variable concentration $(\mathrm{mM})$ of $2-\mathrm{NPOH}$ on Salmonella typhimurium and E. coli $\mathrm{O} 157: \mathrm{H} 7$ (Shigatoxic).

In order to know the effect of variable $\mathrm{pH}$ of growth medium on the test organisms, $\mathrm{pH}$ of the culture medium was adjusted to 5.0, 6.0, $6.5,7.3$ ( $\mathrm{pH}$ of the dehydrated medium), 8.0, 8.5, 9.0 and 9.5 and the test organisms were allowed for incubation (Table 3). It was noted that none of the 3 bacterial cultures grew in the culture medium (TSB) where $\mathrm{pH}$ was maintained below 7.3. The result suggested that these organisms are sensitive to acidic $\mathrm{pH}$ and the effect of 2-NPOH on these organisms could be assessed adopting the standard media pH 7.3 and above. 
Table.1 Minimum inhibitory concentration (MIC) (in vitro) of 2-NPOH

\begin{tabular}{|c|c|c|c|c|c|c|}
\hline & \multicolumn{6}{|c|}{ Hours of incubation } \\
\hline & \multicolumn{6}{|c|}{ Salmonella typhimurium } \\
\hline $\begin{array}{l}\text { Molar Concentration of } \\
\text { 2-NPOH }\end{array}$ & 6 & 12 & 24 & 48 & 96 & 120 \\
\hline $1 \mathrm{mM}$ & + & + & + & + & + & + \\
\hline $1.5 \mathrm{mM}$ & + & + & + & + & + & + \\
\hline $2 \mathrm{mM}$ & + & + & + & + & + & + \\
\hline $2.5 \mathrm{mM}$ & + & + & + & + & + & + \\
\hline $3.0 \mathrm{mM}$ & + & + & + & + & + & + \\
\hline $3.5 \mathrm{mM}$ & - & - & - & - & - & - \\
\hline \multirow[t]{2}{*}{$3.25 \mathrm{mM}$} & - & - & + & + & + & + \\
\hline & \multicolumn{6}{|c|}{ STEC } \\
\hline $1 \mathrm{mM}$ & - & + & + & + & + & + \\
\hline $1.5 \mathrm{mM}$ & - & - & - & - & - & - \\
\hline \multirow[t]{2}{*}{$1.25 \mathrm{mM}$} & - & - & + & + & + & + \\
\hline & \multicolumn{6}{|c|}{ Salmonella gallinarum } \\
\hline $1 \mathrm{mM}$ & - & + & + & + & + & + \\
\hline $1.5 \mathrm{mM}$ & - & - & - & - & - & - \\
\hline $1.25 \mathrm{mM}$ & - & - & + & + & + & + \\
\hline
\end{tabular}

$(-)=$ no growth $;(+)=$ presence of growth.

Table.2 Effect of 2-NPOH on aerobic growth rate of test bacterial culture

\begin{tabular}{|c|c|c|c|}
\hline & \multicolumn{3}{|c|}{ Hours of incubation } \\
\hline 2-NPOH Concentration & 6 & 12 & 24 \\
\hline \multicolumn{4}{|c|}{ Salmonella typhimurium } \\
\hline 2-NPOH not added. & $7 \times 10^{6} \mathrm{cfu} / \mathrm{ml}$ & $20 \times 10^{6} \mathrm{cfu} / \mathrm{ml}$ & $41 \times 10^{6} \mathrm{cfu} / \mathrm{ml}$ \\
\hline $3.0 \mathrm{mM}$ & $70 \times 10^{3} \mathrm{cfu} / \mathrm{ml}$ & $1.7 \times 10^{6} \mathrm{cfu} / \mathrm{ml}$ & $2.5 \times 10^{6} \mathrm{cfu} / \mathrm{ml}$ \\
\hline \multicolumn{4}{|c|}{ STEC } \\
\hline 2-NPOH not added. & $20 \times 10^{6} \mathrm{cfu} / \mathrm{ml}$ & $65 \times 10^{6} \mathrm{cfu} / \mathrm{ml}$ & $170 \times 10^{6} \mathrm{cfu} / \mathrm{ml}$ \\
\hline $1.0 \mathrm{mM}$ & $1.4 \times 10^{6} \mathrm{cfu} / \mathrm{ml}$ & $2.4 \times 10^{6} \mathrm{cfu} / \mathrm{ml}$ & $3.5 \times 10^{6} \mathrm{cfu} / \mathrm{ml}$ \\
\hline \multicolumn{4}{|c|}{ Salmonella gallinarum } \\
\hline 2-NPOH not added. & $11 \times 10^{6} \mathrm{cfu} / \mathrm{ml}$ & $35 \times 10^{6} \mathrm{cfu} / \mathrm{ml}$ & $150 \times 10^{6} \mathrm{cfu} / \mathrm{ml}$ \\
\hline $1.0 \mathrm{mM}$ & $75 \times 10^{3} \mathrm{cfu} / \mathrm{ml}$ & $1.5 \times 10^{6} \mathrm{cfu} / \mathrm{ml}$ & $2.7 \times 10^{6} \mathrm{cfu} / \mathrm{ml}$ \\
\hline
\end{tabular}

Table.3 Effect of variable $\mathrm{pH}$ of growth medium on the test organisms

\begin{tabular}{|l|c|c|c|c|c|c|c|c|}
\hline & \multicolumn{7}{|c|}{ pH } \\
\cline { 2 - 10 } Organism & 5.0 & 6.0 & 6.5 & 7.3 & 8.0 & 8.5 & 9.0 & 9.5 \\
\hline Salmonella typhimurium & - & - & - & + & + & + & + & + \\
\hline Shigatoxic E. coli $($ STEC) & - & - & - & + & + & + & + & + \\
\hline Salmonella gallinarum & - & - & - & + & + & + & + & + \\
\hline
\end{tabular}


Table.4 Effect of 2-NPOH on growth* of the bacteria in medium with different $\mathrm{pH}$

\begin{tabular}{|c|c|c|c|c|c|}
\hline & \multicolumn{5}{|c|}{ pH } \\
\hline \multirow{2}{*}{$\begin{array}{l}\text { 2-NPOH } \\
\text { Concentration }\end{array}$} & 7.3 & 8.0 & 8.5 & 9.0 & 9.5 \\
\hline & \multicolumn{5}{|c|}{ Salmonella typhimurium } \\
\hline $\begin{array}{l}\text { 2-NPOH } \\
\text { not added }\end{array}$ & $20 \times 10^{6}$ & $19 \times 10^{6}$ & $19 \times 10^{6}$ & $19 \times 10^{6}$ & $20 \times 10^{6}$ \\
\hline $3.0 \mathrm{mM}$ & $1.75 \times 10^{6}$ & $1.70 \times 10^{6}$ & $1.75 \times 10^{6}$ & $1.70 \times 10^{6}$ & $1.70 \times 10^{6}$ \\
\hline \multicolumn{6}{|c|}{ STEC } \\
\hline $\begin{array}{l}\text { 2-NPOH } \\
\text { not added }\end{array}$ & $65 \times 10^{6}$ & $64 \times 10^{6}$ & $65 \times 10^{6}$ & $64 \times 10^{6}$ & $65 \times 10^{6}$ \\
\hline \multirow[t]{2}{*}{$1.0 \mathrm{mM}$} & $2.6 \times 10^{6}$ & $2.6 \times 10^{6}$ & $2.4 \times 10^{6}$ & $2.6 \times 10^{6}$ & $2.6 \times 10^{6}$ \\
\hline & \multicolumn{5}{|c|}{ Salmonella gallinarum } \\
\hline $\begin{array}{l}\text { 2-NPOH } \\
\text { not added }\end{array}$ & $35 \times 10^{6}$ & $35 \times 10^{6}$ & $35 \times 10^{6}$ & $34 \times 10^{6}$ & $35 \times 10^{6}$ \\
\hline $1.0 \mathrm{mM}$ & $1.55 \times 10^{6}$ & $1.65 \times 10^{6}$ & $1.50 \times 10^{6}$ & $1.55 \times 10^{6}$ & $1.50 \times 10^{6}$ \\
\hline
\end{tabular}

*Unit of bacterial growth is $\mathrm{cfu} / \mathrm{ml}$; Incubation hour- overnight.

Therefore, bacteriological culture was set in TSB having different alkaline $\mathrm{pH}(7.3,8.0$, $8.5,9.0$ and 9.5) and supplemented with 2$\mathrm{NPOH}$ with a concentration of immediate below MIC molarity viz. for Salmonella typhimurium (3.0 mM 2-NPOH); STEC \& Salmonella gallinarum (1.0 mM 2-NPOH).

It was observed that overnight broth culture of Salmonella typhimurium grown in the medium (without 2-NPOH) with $\mathrm{pH} 7.3,8.0$, $8.5,9.0$ and 9.5 yielded $20 \times 10^{6} \mathrm{cfu} / \mathrm{ml}$; however, when such medium was supplemented with $3.0 \mathrm{mM} 2-\mathrm{NPOH}$ (MIC is $3.5 \mathrm{mM}$ ) the recovered growth was from $1.7 \mathrm{X} 10^{6} \mathrm{cfu} / \mathrm{ml}$ to $1.75 \mathrm{X} 10^{6} \mathrm{cfu} / \mathrm{ml}$ (Table 4$)$. Similarly, STEC exhibited $65 \times 10^{6} \mathrm{cfu} / \mathrm{ml}$ in 2-NPOH free medium of different alkaline $\mathrm{pH}$; however, growth population was reduced to a range of $2.4 \times 10^{6} \mathrm{cfu} / \mathrm{ml}$ to $2.6 \times 10^{6}$ $\mathrm{cfu} / \mathrm{ml}$ when allowed to grow in the medium supplemented with $1.0 \mathrm{mM} 2-\mathrm{NPOH}$ (MIC is $1.5 \mathrm{mM}$ ) (Table 4). Likewise, growth population of Salmonella gallinarum propagated $\left(35 \times 10^{6}\right)$ in $2-\mathrm{NPOH}$ free medium of different alkaline $\mathrm{pH}$ and growth population reduced to a range of $1.5 \times 10^{6}$ $\mathrm{cfu} / \mathrm{ml}$ to $1.65 \times 10^{6} \mathrm{cfu} / \mathrm{ml}$ (Table 4) in the medium supplemented with $1.0 \mathrm{mM} 2-\mathrm{NPOH}$ (MIC is $1.5 \mathrm{mM}$ ). The findings revealed the bacteriostatic effect of 2-NPOH in its subMIC dose, even in variable alkaline $\mathrm{pH}$ of growth medium.

To know the variation, if any in growth inhibitory effect (in-vitro) of 2-NPOH on the field isolates of the test bacteria; the assay of MIC was performed in field isolates of STEC $(\mathrm{n}=12)$ and Salmonella gallinarum $(\mathrm{n}=5)$ where observations were recorded in similar line to reference culture.

In the in-vivo assay, TBC in fresh chick was recorded to be $23 \times 10^{6}$ per gm of faeces and reduced to $14.6 \times 10^{6} \mathrm{cfu}$ on use of $2-\mathrm{NPOH}$ (MIC dosage). While young grown culture of 
STEC was fed to a fresh study group of chicks, the TBC was recorded as $33 \times 10^{7}$ cfu per gram of faeces. Subsequently, on oral feeding of 2-NPOH (MIC dosage) in this study group, TBC was noted to be reduced to $11.2 \times 10^{6} \mathrm{cfu}$ per gram of faeces.

Similarly, for challenge study with Salmonella typhimurium, the TBC was reduced from $26 \times 10^{7}$ to $10.5 \times 10^{6} \mathrm{cfu}$ per gram of faeces. Likewise, for Salmonella gallinarum, the TBC was reduced from $29 \times 10^{7}$ to $9.4 \times 10^{6}$ cfu per gram of faeces. The present study findings indicated that 2-NPOH in its MIC dosage in chick facilitates its growth inhibitory effect on STEC, Salmonella typhimurium and Salmonella gallinarum and reduced the carriage of the intestinal bacteria at a significant level. Above all, the study observations suggested that 2-NPOH may be used as an alternative of scheduled antibiotics supplemented in poultry feed in order to reduce the intestinal carriage of common aerobic bacteria of public health importance.

\section{Acknowledgement}

The authors are thankful to the Director, ICAR-Indian Veterinary Research Institute (IVRI), Izatnagar, U.P. for providing research facilities to carry out this work.

\section{References}

Adhikari, P.A., Cosby, D.E., Cox, N.A. and Kim, W.K. 2016. Efficacy of 2nitropropanol and 2-nitroethanol to reduce the growth of Salmonella Enteritidis, Salmonella Heidelberg, Salmonella Kentucky and Salmonella typhimurium in vitro. In: International Poultry Scientific Forum, Georgia World Congress Center, Georgia, Poult. Sci. 95 (E-Suppl. 1), pp-268.

Adhikari, P.A., Cosby, D.E., Cox, N.A. and Kim, W.K. 2017. Effect of 2- nitroethanol and 2- nitropropanol on the colonization and ileal immune gene expression in White Leghorns after challenge with Salmonella enteritidis. In: International Poultry Scientific Forum, Georgia World Congress Center, Atlanta, Poult. Sci. 96 (E-Suppl. 1), pp-304.

Anderson, R. C., Buckley, S.A., Kubena, L.F., Stanker, L.H., Harvey, R.B. and Nisbet, D.J. 2000. Bactericidal effect of sodium chlorate on Escherichia coli O157:H7 and Salmonella typhimurium DT104 in rumen contents in vitro. J. Food Protect. 63:1038-1042.

Anderson, R.C., Harvey, R.B., Byrd, J.A., Callaway,T.R., Genovese, K.J., Edrington, T.S., Jung, Y.S., McReynolds, J.L. and Nisbet, D.J. 2005. Novel preharvest strategies involving the use of experimental chlorate preparations and nitro-Based compounds to prevent colonization of food-producing animals by foodborne pathogens. Poult. Sci., 84: 649-854.

Cassir, N,, Benamar, S. and La Scola, B. 2016. Clostridium butyricum: from beneficial to a new emerging pathogen. Clin. Microbiol. Infect. 22(1):37-45.

Centres for Disease Control and Prevention (CDC). 2016. Foodborne Disease Outbreak Surveillance System; Annual Report, 2016.

Centres for Disease Control and Prevention (CDC). 2018. Foodborne illnesses and Germs Food Safety CDC (https://www.cdc.gov/foodsafety/foodb orne-germs.html).

Grande Burgos, M. J., Pulido, R.P., del Carmen López Aguayo, M., Gálvez, A. and Lucas R. 2014. The cyclic antibacterial peptide Enterocin AS-48: Isolation, mode of action, and possible food applications. Int. J. Mol. Sci., 15(12):22706-22727. 
Hao, H., Cheng, G., Iqbal, Z., Ai, X., Hussain, H. I., Huang, L., Dai, M., Wang, Y., Liu, Z., and Yuan, Z. (2014). Benefits and risks of antimicrobial use in foodproducing animals. Front. Microbiol., 5, 288.

Jung, Y.S., Anderson, R.C., Byrd, J.A., Edrington, T.S., Moore, R.W., Callaway, T.R., McReynolds, J. and Nisbet, D.J. 2003. Reduction of Salmonella typhimurium in experimentally challenged broilers by nitrate adaptation and chlorate supplementation in drinking water. J. Food Protect., 66: 660-663.

Jung, Y.S., Anderson, R.C., Callaway, T.R., Edrington, T.S., Genovese, K.J., Harvey, R.B., Poole, T.L. and Nisbet, D.J. 2004. Inhibitory activity of 2nitropropanol against select food-borne pathogens in vitro. Lett. Appl. Microbiol., 39: 471-476.

Jung, Y.S., Anderson, R.C., Edrington, T.S., Genovese, K.J., Byrd, J.A., Callaway, T.R. and Nisbet, D.J. 2004. Experimental use of 2-nitropropanol for reduction of Salmonella typhimurium in the ceca of broiler chicks. J. Food Protect., 67: 1045-1047.

Ortega, B.I., Grande, B. M.J., Pérez-Pulido, R., Gálvez, A. and Lucas R. 2018.
Treatment with high-hydrostatic pressure, activated film packaging with Thymol Plus Enterocin AS-48, and its combination modify the bacterial communities of refrigerated Sea Bream (Sparus aurata) fillets. Front. Microbiol., 28(9): 314.

Rahayu, W. P., Fardiaz, D., Kartika, G. D., Nababan, H., Fanaike, R. and Puspitasari, R. 2016. Estimation of economic loss due to food poisoning outbreaks. Food Sci. Biotechnol., 25 (Suppl 1), 157-161.

Strompfova, V. and Laukova, A. 2007. In vitro study on bacteriocin production of Enterococci associated with chickens. Anaerobe, 13 (5-6): 228-237.

USDA 2014. U.S. Foodborne Illnesses Cost More Than \$15.6 Billion Annually. https://www.foodsafetynews.com/2014/ 10/foodborne-illnesses-cost-usa-15-6billion-annually.

WHO 2015. 'WHO estimates of the global burden of foodborne diseases'. https://www.who.int/foodsafety/areas_ work/foodborne-diseases/ferg/en/

Yang, S.C, Lin, C.H., Aljuffali, I.A. and Fang, J.Y. 2017. Current pathogenic Escherichia coli foodborne outbreak cases and therapy development. Arch. Microbiol., 199 (6):811-825.

\section{How to cite this article:}

Suresh Chandra Das, Pramod Kumar Nanda and Uttam Kumar Bandyopadhyay. 2018. Growth Inhibitory Effect of 2-Nitropropanol on Foodborne Bacteria of Public Health Importance. Int.J.Curr.Microbiol.App.Sci. 7(12): 2261-2268. doi: https://doi.org/10.20546/ijcmas.2018.712.257 